\title{
RESURRECTION AND PAROUSIA OF THE SON OF MAN
}

\author{
George R. Beasley-Murray
}

Introduction

Christ died,

Christ rose,

Christ will come again.

This age-old confession of the Church, which is especially associated with the Lord's Supper, is rooted in the very beginnings of the Christian faith.

To declare that Christ was raised of necessity is to speak of the Messiah who died. More specifically, it relates to Jesus, crucified under Pontius Pilate at the instigation of Jewish rulers. The death and the resurrection of Jesus are manifestly inseparable for Christian faith, as indeed for Christian theology; that is attested alike in the records of the primitive kerygma and in the developed apostolic writings. But whereas the resurrection of Jesus self-evidently was preceded by his death, the Easter resurrection is the absolutely inalienable presupposition of the gospel, for without it there would have been no gospel to be proclaimed. 'God went down with the Titanic' said a survivor of the shipwreck, overwhelmed by the tragedy of the event. So also faith in Jesus as redeemer-king died when Jesus died on the cross (cf. Lk. 24:18-21), but through his resurrection it came alive with vast dimensions.

The centrality of the resurrection of Jesus for faith, however, has a future as well as a past dimension. Resurrection is essentially a feature of the last times, the outstanding element of hope for the people of God, since it connotes entry upon life in the eternal kingdom of God. An examination of the NT makes it evident that the resurrection of Jesus was linked not alone with his death but also with his parousia. The nature and significance of this connection will be the primary theme of this study. 


\section{Resurrection and the Parousia: Texts}

1. The earliest of these is a statement in 1 Thessalonians 1:9-10, in all probability a confessional fragment cited by Paul:

You turned to God from idols, to serve a living and true God, and to wait for his Son from heaven, the one whom he raised from the dead Jesus, who rescues us from the wrath that is coming. ${ }^{1}$

The language of the first two lines is reminiscent of apostolic preaching to pagans, such as is found in Acts 14:15. That of the last three is notable in its emphasis on a lively anticipation of the parousia of the Son of God, whom God raised from the dead, and who rescues his own from the coming judgment. It is commonly assumed that the composer of the passage had in mind the kind of thought contained in Luke 12:8-9, which affirms the Son of Man's confession of his followers at the judgment, so 'rescuing' them from the wrath to come, and that could well be right. On the other hand, the link in the primitive kerygma between the death and resurrection of Christ with forgiveness of sins (cf. especially Rom. 3:25; 1 Cor. 15:4-5) suggests that after Easter the connection between the death, resurrection and parousia of Jesus will have been axiomatic for the earliest believers, hence that the redemption achieved through the death and resurrection of the Son of Man, Jesus, reaches its goal at the bar of God, i.e. at the parousia. ${ }^{2}$

2. It would appear that Paul alludes to another confessional statement in 1 Thessalonians 4:14:

If we believe that Jesus died and rose again, so also God will bring with him those who have fallen asleep through Jesus.

\footnotetext{
${ }^{1}$ For the significance of this text see F. Hahn, The Titles of Jesus in Christology, (London, 1969), 286; J. Becker, Auferstehung der Toten im Urchristentum, (Stuttgart, 1976) 33-38.

'The term 'rescue' (Greek $\dot{0} 0 \mu_{\alpha} \alpha_{\mathrm{l}}$ ) is frequent in the OT for delivering people from their enemies-from Egypt, Assyria, captivity-and so can render the Hebrew term 'to redeem', גאל In the New Testament in eschatological contexts it denotes 'final preservation from being snatched out of the eternal salvation which God has promised'. W. Kasch, TDNT, VI, 1003.
} 
It would not have been inappropriate if the second line of the quotation had read, 'so also God will raise with him those who have fallen asleep through Jesus'. Such an affirmation is thoroughly in line with Paul's teaching in Romans 6, and it could have stood in the original wording used by the apostle; in that case Paul will have changed the verb 'will raise' to 'will bring' in view of the instruction on the parousia he is about to state. In reality there is no essential difference between the two forms of utterance, since the affirmation, 'God will bring with Jesus', clearly speaks of resurrection of God's people at the parousia of Jesus, and that is the event wherein God will 'raise' the believing dead. The saying is based on the conviction that the Easter resurrection of Jesus will be shared by his people at the parousia. This statement is expanded and applied to the Thessalonian believers in the sentences that follow, which describe the parousia and the resurrection and 'rapture' of the saints. It is worthy of note that the affirmation of v. 15 that at the parousia surviving believers will not 'precede' those who have died is confessedly deduced from a 'word of the Lord', i.e. a saying of Jesus handed on in the evangelic traditions; there is reason to believe that the 'word' referred to is none other than that which is preserved in Mark 13:26-27 parallels.

3. A remarkable utterance concludes Luke's record of Paul's address to the Athenians, Acts 17:30-31:

While God has overlooked the times of human ignorance, now he commands all people everywhere to repent, because he has fixed a day on which he will have the world judged in righteousness by a man whom he has appointed, and of this he has given assurance to all by raising him from the dead.

Everything in the address up to this point is preparation for the gospel; here the gospel is encapsulated in a sentence. Of one thing we may be sure: Luke had no intention of suggesting that the report was complete-the whole sermon can be read aloud in two minutes. The introduction is extraordinary in its representation of the lengths to which a gospel preacher can go in citing with approval ideas of God and his relations with man expressed by non-Christian philosophers. The citation from Epimenides in v. 28, 'In him we live and move and have our being', affirms God to be the Creator and Sustainer of 
all human existence, and that of Aratus, 'We too are his offspring', conveys a similar concept. The reality of God's selfrevelation to humanity outside the scriptures is affirmed in a manner comparable to the exposition of the Word in the prologue to the Fourth Gospel. But the declaration that God, who earlier overlooked the ignorance of man, now commands all humankind to repent, presupposes that a final revelation of God has now been given to the world, in the light of which all people must 'repent', i.e. turn to God. This is spelled out in three utterances: (i) God has appointed a day for the world to be judged 'in righteousness' (an allusion to Ps. 9:8, relating to the Day of the Lord, which for Paul has become the Day of Jesus Christ, e.g. Phil. 1:6); (ii) he has appointed a Man through whom the judgment is to take place, an astonishing statement, which has its analogies in the vision of the 'one like a son of man' to whom the kingdom of God is given (Dn. 7:13), but more directly the teaching of Jesus relating to the decisive witness of the Son of Man in the judgment (e.g. Lk. 12:8-9) and his coming in power and glory as Lord of the kingdom and Judge of humanity (see e.g. Mk. 14:62; Mt. 25:31; Jn. 5:27); (iii) proof of this appointment of the Son of Man as Judge has been given by God in that he raised him from the dead.

The assumption that Paul will have further expounded this connection between the day of judgment and the resurrection of Jesus is demanded by the circumstances of the address. According to Luke some of the philosophers who listened to Paul had received the impression that he was 'a proclaimer of foreign divinities', for 'he was telling the good news about Jesus and the resurrection' (v. 18). This association of 'Jesus and the resurrection' apparently had led them to understand that Paul proclaimed two gods - Jesus and Anastasis (Resurrection). They therefore brought him before the Areopagus with the request that he explain this new teaching. If Paul in his normal preaching of the gospel commonly emphasized the significance of the resurrection of Jesus, he will certainly have taken this opportunity to make his meaning plain. Accordingly what Luke has done in v. 31 is to single out one supremely important element in Paul's preaching of 'Jesus and the resurrection': the Easter event is God's demonstration that he has appointed Jesus to be the one through whom the 
destiny of all humankind is determined; manifestly that judgment will be performed 'in righteousness', since in the resurrection God set his seal on the fact that Jesus is the embodiment of the righteousness of God, alike in his life and in his death (cf. the primitive couplet in $1 \mathrm{Tim}$. 3:16, 'He was revealed in flesh justified in spirit'; Acts 3:14-15; Jn. 16:8-11). ${ }^{3}$

II.

The linking of the resurrection and the parousia of Jesus throws light on both events. This will confirm:

(1) First, the connection between the resurrection and the parousia makes plain, what in any case is commonly acknowledged, that the resurrection of Christ is a truly eschatological event. It is not to be thought of in terms of God imparting a 'kiss of life' to Jesus, whereby he resumes an existence of the old order; rather it is to be conceived of as the revelation of Christ's new existence in a 'transformed' body in God's new world. Observe the placing of the term 'transformed' in quotation marks. If we are asked to define what we mean by it in this context we have to confess that we cannot do so. The NT does not describe the mode of Christ's resurrection, and we are unable to fill in the lacuna. In the resurrection of Jesus we are conscious of standing before God's eschatological secret, the mystery of the new creation. Paul assumes this understanding in his well known utterance of 2 Corinthians 5:17:

If anyone is in Christ, there is a new creation; everything old has passed away; see, everything has become new! (New RSV)

This appears to mean that to enter into the koinonia of Christ is to step into the new creation that came into being in the Easter of the Son of God. Before any creature could proclaim, 'Christ is risen', there was the new creation in the person of the risen Lord.

\footnotetext{
${ }^{3}$ Note G. Delling, 'The Significance of the Resurrection for Faith in Jesus Christ', C.F.D. Moule (ed.), in The Significance of the Message of the Resurrection for Faith in Jesus Christ, SBT 2nd ser. 8. (London, 1968) 89, on the implications of Acts 17:31: 'According to Acts, the significance of the raising of Jesus lies in the fact that Jesus is thereby confirmed or constituted as him on whose name-that is, on whose person-the possibility of repentance, forgiveness and therefore redemption at the judgment depends'.
} 
This point needs to be emphasized, for it is perhaps insufficiently appreciated. It is stressed by Walter Künneth time and again in his work on the theology of the Resurrection.

The primal miracle of the Resurrection is eschatologically determined. It is a primal miracle like that of the creation of the world, but in distinction from the provisionality and perishability of the latter, in the former the finality and imperishability of a new final creation breaks through once for all. ${ }^{4}$

Karl Heim similarly asserts: "The Resurrection of Christ is something that is fundamentally distinguished from all events which take place on the plane of the present worldtime, namely the beginning of the consummation of the world, the beginning of the end-time victory of God over this earth. ${ }^{5}$ It is, of course, a beginning which anticipates an end. So Neville Clark rightly affirms, 'As the Resurrection signified the inauguration of a new world, so the parousia must mark that total consummation which is the new heaven and the new earth (Is. 65:17, 66:22; 2 Pet. 3:13; Rev. 21:1)' ${ }^{6}$

(2) If the resurrection of Jesus is to be viewed as God's eschatological action in and through him, whereby new creation is initiated, the question arises as to its relation to that element in the saving action of God in Christ from which it is inseparable, namely the death of Jesus. It is significant that Paul's declaration about new creation in Christ is flanked by statements relating to the redemptive deed of Christ. Prior to it is the terse utterance:

We are convinced that one has died for all; therefore all died. And he died for all, so that those who live might live no longer for themselves, but for him who died and was raised for them, (2 Cor. 5:14-15).

following by the affirmation of Christ's death as a means of reconciliation:

All this (namely life in the new creation in Christ) is from God, who reconciled us to himself in Christ. . For our sake he made him to be sin who knew no sin, so that in him we might become the righteousness of God, (2 Cor. 5:18-21).

${ }^{4}$ W Künneth, Theologie der Auferstehung, (München, Claudius Verlag 1951) 65.

5 Jesus der Weltoollender, 175

'Interpreting the Resurrection, (1967), 66. 
The basis for such assertions is the understanding of Christ as the Representative Man, the Last Adam. When he died, all whom he represented died. When he rose, all whom he represented rose. When hearers of the gospel receive that message in faith, what happened for them becomes operative in them. They enter into the koinonia of the Christ who died and rose, and so participate in the effectiveness of that death and resurrection for sinners. That is the meaning of the sacraments in Paul's teaching. It is the heart of his exposition of baptism in Romans 6, namely unity with Christ in his death and resurrection, with its consequences of end of life apart from God for entry on life in Christ, and renunciation of life in sin for life befitting the new creation. So also to drink the 'cup of blessing' is to participate in the blood of Christ, and to eat the broken bread is to share in the body of Christ (1 Cor. 10:16); such koinonia embraces not only the benefits of the sacrifice of Christ but life in the risen Lord.

No wonder that Paul said, 'All this is of God'! Only God in Christ could bring about a death which is the death of death, and this he did through a death which directly led to and hence initiated resurrection from the dead. That is kingdom-of-God action, eschatological action for life from the dead for the whole human race. ${ }^{7}$

(3) Such eschatological action of God in Christ leads to the question of its relation to the service of the kingdom of God that took place in the ministry of Jesus. All four gospels view that 'service' as eschatological. All four represent the miracles of Jesus as signs of the presence of the kingdom of God in and with him, and they all report words of his that make its presence plain (e.g. Mt. 11:5-6, 11:12, 13:16-17; Mk. 3:27; Lk. 4:16-21, 17:20-21). The burden of the parables of Jesus, surely the most recognizably authentic elements of the Jesus tradition, is that in his words and deeds God was in process of fulfilling his promise to establish the saving sovereignty, with an implicit

\footnotetext{
${ }^{7}$ Note that in the Fourth Gospel the depiction of the death of Christ as his 'lifting up' (Jn. 3:14-15, 8:28, 13:31-32) entails the concept of the death and resurrection of the Son of Man as one indivisible event; the Christ is lifted up on the cross thence to the right hand of God. See G. Bertram, TDNT VIII, 466; J. Blank, Krisis, (1964), 266; C.K.Barrett, The Gospel according to St. John, (London 1978²) 214.
} 
appeal that his people receive the word, and repent and experience its truth.

That finding is generally accepted by the majority of NT scholars. How, then, does it relate to the understanding that the death-resurrection of Jesus is the fundamental eschatological act of God in Christ? Ulrich Wilckens urged that in face of the Jewish rejection of the message of Jesus, and of his being handed over for crucifixion, the resurrection of Jesus was God's eschatological confirmation of the authority and truth of the message of Jesus. He wrote, The dominant concern of the earliest preaching of the resurrection of Jesus was not that Jesus who had died had come to life, but that Jesus, the preacher of the kingdom of God who had died, had now had his preaching eschatologically authenticated, and had therefore become the standard of judgment for eschatological salvation and damnation, as he had in fact claimed to be in his whole ministry. ${ }^{8}$

To this Marxsen objected that if that were so, the earthly Jesus would stand as a mere parenthesis, which would disappear through the resurrection. 'What Jesus did and wrought would in that case have been no more than a prelude', whereas 'the original traditions speak only of Jesus' direct claim to sovereignty, to a ministry which in itself raised an eschatological claim, but which did not demand ratification. . . It is not the resurrection which is the decisive datum, but Jesus was the 'datum', his words and deeds'. 9

These alternatives are surely complementary, rather than mutually exclusive. An important function of the gospels is to make it clear that the acts and the words of Jesus were as truly eschatological as his death and resurrection, yet at the same time they in no way differ from the other NT writings in their estimate of the eschatological significance of the crucifixion-resurrection. ${ }^{10}$

\footnotetext{
${ }^{8}$ 'The Tradition-history of the Resurrection of Jesus', in C.F.D. Moule op. cit., 66-7.

9'The Resurrection of Jesus as a Historical and Theological Problem', in C.F.D. Moule, op. cit., 45-7.

${ }^{10}$ Not the least significant element of C.H. Dodd's work was to emphasize this throughout his writings. See e.g. his exposition of the eschatological kerygma in the gospels, The Apostolic Preaching and its Development (London, Hodder
} 
We accordingly are led to affirm that Jesus was the Mediator of the kingdom of God in the totality of his action for God and man, including his ministry, death and resurrection, for the kingdom of God was coming through all that he was, and said and did. It is not without cause that we speak of 'the Christ event' as one!

\section{III.}

If then, as we have seen, the parousia throws light on the resurrection of Christ, it is also true that the resurrection illuminates the parousia, not least in virtue of the resurrection anticipating the completion of God's saving action in Christ at the parousia.

(1) First we may affirm that the resurrection of Jesus is the one clue that we have to the nature of the parousia. This is because the NT represents on the one hand the resurrection as the revelation of Christ the Saviour as the sovereign Lord alive from the dead and exalted to God's right hand, and on the other the parousia as the revelation of Christ in the power and glory of the consummated kingdom of God.

This feature of the parousia as personal revelation is not to be taken as self-evident. We are becoming accustomed to acknowledge that NT descriptions of the coming of the Lord at the end of the age freely draw on images in the OT of the coming of God and the Day of the Lord. We are also aware that theophany in the OT is by no means confined to portrayals of the end time events. An early example of a theophany in history occurs in the Song of Deborah:

Lord, when you went out from Seir, When you marched from the region of Edom, the earth trembled, and the heavens poured,

\& Stoughton 19442 ${ }^{2}$ 46-56, and especially 59: 'Of the life of Jesus he (Paul) makes little except as preparation for his death. Here the Synoptic Gospels do more justice to that part of the kerygma which recited the facts of the life of Jesus as an integral element in the eschatological process. Now for John the whole life of Jesus is in the fullest sense a revelation of his glory. What was true of Christ's work in the Church after his resurrection was already true of his words and works in the flesh. By them, as truly as by his death and resurrection, he brought life and light into the world'. 
the clouds indeed poured water.

The mountains quaked before the Lord, the One of Sinai, before the Lord, the God of Israel, (Jdg. 5:4-5)

Two features of theophany in general are illustrated here; the first is that the coming of God is for action in the world, in this case for the salvation of his people at the Exodus; the second is the depiction of nature reacting in terror before the presence of the almighty Creator. ${ }^{11}$ The latter element is elaborated in all kinds of ways in the OT, especially in relation to the Day of the Lord. In the hymn of Habakkuk 3, the prophet asks for the judgment and salvation of God at the Exodus to be repeated in a day of the Lord on an oppressive nation and the rescue of Israel; in so doing the Exodus event is described in the colourful language of theophany in such a fashion that no historical reconstruction of God's coming in the past and no clear anticipation of concrete events in the future could possibly be deduced from it. The like applies to most of the portrayals of the coming of the Lord in the NT, above all to those in the Book of Revelation. But there is one important difference: whereas in the OT God's 'coming' primarily denotes his deeds of judgment and deliverance in the world, without any manifestation of his being, in the NT the parousia associates acts of judgment and deliverance with the revelation of the Lord in power and glory.

This may be illustrated by the answer of Jesus to the High Priest at his trial: when asked whether he was the Messiah. Jesus replied, 'I $\mathrm{am}^{\prime}$ ' and then unfolded the implications of that claim: 'You will see the Son of Man seated at the right hand of the Power, and "coming with the clouds of heaven"' (Mk. 14:62). The language is that of theophany, as in Dan. 7:13, but if the judges of Jesus are to see him as the enthroned Lord of the kingdom of God, and coming to exercise his authority, that implies a revelation or appearance of his person. ${ }^{12}$ The same essential concept is embodied in Mk. 13:24-27 in

\footnotetext{
${ }^{11}$ For a thorough examination of the origin and development of the theophany concept in the Old Testament see Jörg Jeremias, Theophanie: Die Geschichte einer alttestamentlichen Gattung, (Neukirchen-Vluyn 1965).

${ }^{12}$ The appearance, or revelation of the Son of Man in Mk. 14:62, as in Dn. 7:13, implies a coming from heaven to earth, not an ascent heavenwards. See the discussion of the passage in the author's Jesus and the Kingdom of God, (Grand Rapids/Exeter 1986) 300-3.
} 
a setting that uses Day of the Lord language:

The sun will be darkened, and the moon will not give her light, and the stars will be falling from heaven, and the powers in the heavens will be shaken.

Then they will see 'the Son of Man coming in clouds' with great power and glory.

There is no suggestion in this passage of the dissolution of the universe. It is the old theophanic representation of the heavens and earth in terror and confusion before the overwhelming might of the Lord when he steps into the world to act in judgment and salvation. In this case, however, everyone sees the Son of Man in his glory-God's representative, through whom he saves and judges. John the Seer in the prologue to the Revelation makes this theme the motto of his book:

Look! He is coming with the clouds;

every eye will see him,

even those who pierced him;

and on his account all the tribes of the earth will wail.

So it is to be. Amen. (Rev. 1:7).

They shall 'see' him, as the disciples saw him at Easter, when his glory was veiled, and as Saul of Tarsus saw him in his unveiled glory on the Damascus Road. They shall 'see', and know who he is: the Lord of the kingdom, exalted at his Easter and now revealed as the Lord of the universe. ${ }^{13}$

(2) We recall that in Christ risen from the dead the new creation was present before any human being knew it, and since that time all who through the Spirit enter into the koinonia of Christ participate in the new creation, i.e. in the life of the kingdom of God. As the parousia is for the purpose of consummating the kingdom of God, so it signifies the bestowal of fulness of life in resurrection like Christ's.

This theme, we recall, is developed in 1 Thessalonians 4 , and at greater length in 1 Corinthians 15 . It is significant

${ }^{13} \mathrm{Cf}$. W. Künneth, Theologie der Auferstehung, (München 1951) 75 'As a distinction must be made between the reality of the resurrection as such and its 'appearance', so on the other hand we must distinguish between an unmediated, perfected revelation, for which the disciples still wait, and a fragmentary and veiled revelation in which they shared in the (resurrection) appearances'. 
that in the latter passage Paul begins his exposition of the doctrine of resurrection with a declaration of the facts of Christ's death and burial, resurrection and appearances. It is likely that the Corinthian Christians had not grasped the connection between Christ's resurrection at Easter and the destiny of humanity. Indeed, the popular idea that the Corinthians assumed the doctrine of immortality of the soul, and so repudiated resurrection as a crude notion, is seriously to be doubted. ${ }^{14}$ Greek cemetery inscriptions show that most Greeks had no hope at all of life beyond the grave. The experience of ecstasy in the Spirit and spiritual gifts was no necessary guarantee to immature converted pagans of life beyond death, any more than church membership today gives assurance of immortality to all in the churches.

The slogan 'Dead men don't rise' will have been uttered by the Corinthian objectors to Paul's teaching. His answer that in that case Christ himself hasn't been raised, is not based on the thought that since Jesus was a man, he too was doomed to perpetual death; rather the determining factor is the solidarity of Jesus with all humankind: as the representative man his death entailed the death of all and his resurrection the resurrection of all. The fundamental fact in Paul's teaching about resurrection is not really Hebrew anthropology, but the death and resurrection of the Son of God-Son of Man Jesus and his impending parousia for the life of the world. Karl Heim will have had this in view in his affirmation, "The resurrection of Jesus is God's great 'Yes' to life in opposition to all autumnal nostalgia for Nirvana' ${ }^{15}$

Karl Barth, it so happens, made an almost identical statement when he described the parousia as the miracle of the divine 'Yes'. ${ }^{16}$ Heim and Barth were both right. So surely as the resurrection of Jesus was the initiation of the resurrection of all humanity, so the parousia will bring about its perfection within all humanity. Observe, 'all humanity' is involved, not

\footnotetext{
${ }^{14} \mathrm{H}$. Clavier strongly represented this viewpoint in his article, 'Brèves remarques sur la notion de $\pi v \varepsilon v \mu \alpha \tau \kappa o v v \sigma \hat{\omega} \mu \alpha$ in the Festschrift for C.H. Dodd, The Background of the New Testament and Its Eschatology, W.D. Davies \& D. Daube (edd.) (Cambridge, CUP 1964) 358-361.

${ }^{15}$ Jesus der Weltoollender, 184.

${ }^{16}$ The Epistle to the Romans, ET E.C.Hoskyns, (Oxford, 1933) 417.
} 
all humanity, so the parousia will bring about its perfection within all humanity. Observe, 'all humanity' is involved, not simply Christians. Paul's view of Jesus as the last Adam, reversing and overcoming the deadly work of the first Adam, demands that acknowledgement, despite his concentration in 1 Corinthians 15 on the resurrection of believers. And Jesus himself implied the same in his teaching, as when he referred to the men of Nineveh and the Queen of the South rising up in the judgment with his generation (Mt. 12:41-42). ${ }^{17}$

The significant feature of resurrection of humanity in and through Christ is the evident fact that it predicates a continuous relation of God in Christ with every individual. It assumes the existence of that relationship from creation on, through history, in the incarnation, death and resurrection of Christ, and on to the parousia. The whole process has its origin in the love of God, not only its beginning and continuance but also its end. The NT delineation of resurrection concentrates on its aspect as participation in the blessedness of Christ's resurrection glory, something far beyond the concept of immortality of the soul. Emil Brunner cited on more than one occasion the dictum of F.C. Oetinger, "The end of the ways of God is corporeality'. ${ }^{18}$ The saying can be applied in various ways, including the richness of resurrection life, and its aspect of fellowship in redeemed society in contrast to the solitude of a surviving spirit. That reality already belongs to Christian existence as life in the Body of Christ, which looks to the future as the perfection of life in the unity of God's love in Christ and his people (cf. Jn. 17:25). The vision of the City of God in Revelation 21-22 concentrates precisely on this aspect of the perfection of the fellowship of God in Christ with humankind, hence the City is named the 'Bride' of Christ, the object of the divine love, redeemed at infinite cost.

\footnotetext{
${ }^{17}$ See W.G. Kümmel's discussion, Promise and Fulfillment, (London, 1957) 88-91. On this basis $\mathrm{G}$. Gloege is right in affirming that the aspect of judgment as decision over the godless and righteous entails the general resurrection of the dead as conditio sine qua non, in Reich Gottes und Kirche, im Neuen Testament, (Gütersloh, 1929) 180.

${ }^{18}$ See e.g. The Christian Doctrine of the Church, Faith and the Consummation, (London 1962) 438-39. The quotation is from Oetinger's Theologia ex idea vitae deducta, (1765).
} 


\section{Conclusion}

This review of the connection between the resurrection and the parousia of Christ indicates how very closely related they are in the writings of the NT. The resurrection is the anticipation of the parousia, the parousia is the fulfilment of the promise for humanity and the cosmos implied in the resurrection. One outstanding implication of this circumstance should be immediately evident, namely the unity of the redeeming work of Christ for the world. The incarnation of the Son of God was for the purpose of bringing into this world the saving sovereignty of God through his ministry, death and resurrection, issuing in the sending of the Holy Spirit, and finally his parousia. The Easter resurrection made plain the eschatological reality of the process, the parousia completes it. It is one unbroken action of God in Christ, no element of which can be omitted for the fulfilment of God's purpose for his creation. One element alone remains to be fulfilled, the parousia, and of that the resurrection is the promise and pledge.

God has given us a sure and certain hope. His kingdom is among us. With him we press on to its consummation, when the kingdom of this world shall become the kingdom of our God and of his Christ. Then he will reign for ever and ever, and his people will share his reign with him (Rev. 11:15, 22:5). Incomprehensible though it be, the word is as sure as his throne. 